\title{
Effectiveness of an educational program in nursing in the self-care of patients with heart failure: randomized controlled trial ${ }^{1}$
}

\author{
María de los Ángeles Rodríguez-Gázquez² \\ Edith Arredondo-Holguín ${ }^{3}$ \\ Richard Herrera-Cortés ${ }^{4}$
}

Unblinded randomized controlled clinical trial to evaluate the effectiveness of an educational program in nursing (educational meetings, home visits, telenursing and a printed book) in the improvement of self-care behaviors in patients with heart failure was evaluated. Thirtythree people participated in the intervention group and thirty in the control group. At the beginning and at the end of the study (ninth month), Nancy Artinian's Heart Failure Selfcare Behaviors Scale was applied to assess the level of self-care. $66.0 \%$ of the intervention group versus $26.6 \%$ of the control group improved the self-care score by at least $20 \%$ $(p<0.001)$. The Number Needed to Treat was 2.5. The findings suggest that the educational intervention has beneficial effects on the self-care behaviors of people with heart failure. Descriptors: Heart Failure; Self-Care; Education, Nursing; Randomized Controlled Trial.

\footnotetext{
${ }^{1}$ Supported by Facultad de Enfermería y del Comité para el Desarrollo de la Investigación (CODI), Universidad de Antioquia, Colombia.

2 PhD, Associate Professor, Facultad de Enfermería de la Universidad de Antioquia, Colombia.

3 MSc, Associate Professor, Facultad de Enfermería de la Universidad de Antioquia, Colombia.

${ }^{4}$ Undergraduate student, Research Incubator Kairos, Facultad de Enfermería de la Universidad de Antioquia, Colombia.
}

Corresponding Author:

María de los Ángeles Rodríguez-Gázquez Universidad de Antioquia. Facultad de Enfermería Calle 64, 53-09 Medellín, Colombia

E-mail: mariangelesrodriguezg@hotmail.com 


\title{
Efetividade de um programa educativo em enfermagem no autocuidado em pacientes com insuficiência cardíaca: ensaio clínico randomizado
}

Trata-se de ensaio clínico controlado, aleatorizado, sem cegamento, no qual se avaliou a efetividade de um programa educativo de enfermagem (encontros educativos, visitas domiciliárias, tele-enfermagem e cartilha impressa), no melhoramento dos comportamentos de autocuidado em pacientes com insuficiência cardíaca. Participaram 33 pessoas no grupo de estudo e 30 no grupo controle. No início e no final do estudo (nono mês), aplicou-se a Escala de Comportamentos de Autocuidado de Pacientes com insuficiência cardíaca, de Nancy Artinian, para avaliar o nível de autocuidado. Resultados: $66,0 \%$ do grupo de intervenção contra $26,6 \%$ do grupo controle melhoraram em ao menos $20 \%$ da pontuação de autocuidado $(p<0,001)$. O Número Necessário a Tratar (NNT) foi de2,5. Os resultados sugerem que a intervenção educativa de enfermagem estudada tem efeito benéfico sobre comportamentos de autocuidado das pessoas com insuficiência cardíaca.

Descritores: Insuficiência Cardíaca; Autocuidado; Educação em Enfermagem; Ensaio Clínico Controlado Aleatório.

\section{Efectividad de un programa educativo en enfermería en el autocuidado de los pacientes con insuficiencia cardíaca: ensayo clínico controlado}

\begin{abstract}
Ensayo clínico controlado aleatorizado sin cegamiento, con el que se evaluó la efectividad de un programa educativo de enfermería (encuentros educativos, visitas domiciliarias, tele enfermería y cartilla impresa) en el mejoramiento de los comportamientos de autocuidado en pacientes con insuficiencia cardíaca. Participaron 33 personas en el grupo de estudio y 30 en el grupo control. Al inicio y al finalizar el estudio (noveno mes) se aplicó la Escala de Comportamientos de Autocuidado de Pacientes con Insuficiencia cardiaca de Nancy Artinian para evaluar el nivel de autocuidado. Resultados: $66,0 \%$ del grupo de intervención versus $26,6 \%$ del grupo control mejoraron en al menos un $20 \%$ el puntaje de autocuidado $(p<0,001)$. El Número Necesario a Tratar fue 2,5. Los hallazgos sugirieren que la intervención educativa de enfermería estudiada tiene un efecto beneficioso en los comportamientos de autocuidado de las personas con insuficiencia cardiaca.
\end{abstract}

Descriptores: Insuficiencia Cardíaca; Autocuidado; Educación en Enfermería; Ensayo Clínico Controlado Aleatorio.

\section{Introduction}

Heart failure (HF) is a clinical syndrome characterized by high mortality, frequent hospitalization, poor quality of life, multiple comorbidities and a complex therapeutic regimen, resulting in structural or functional cardiac alterations, limiting the heart's ability to fill itself with and expulse blood during the cardiac cycle ${ }^{(1)}$. At the global level, HF is considered a severe public health problem because of its extremely high morbidity and mortality rates ${ }^{(2)}$ and the enormous economic and social costs it generates for patients, their families, health care providers and society in general(3). The increased prevalence of $\mathrm{HF}$ in recent decades is due, among other reasons, to population aging and to higher survival rates, as a result of improvements in diagnosis and treatment methods ${ }^{(4)}$.

The extreme fatigue these patients are victims of, due to the low perfusion of body tissues, influences the worsening of quality of life and personal and social roles 
and leads to a progressive loss of self-care abilities ${ }^{(5)}$; as a result, one of the main challenges nursing faces in care delivery to HF patients is to improve self-care, which Orem defines as the practice of activities that individuals initiate and perform on their own behalf, consciously and continuously, in maintaining life, development, health and well being(6).

It is known that the main conduct-related risk factors for $\mathrm{HF}$ are susceptible to intervention through educational programs, which over time results in decreased probability of readmission and premature death ${ }^{(7)}$. Educational interventions involving HF patients include different strategies: educational meetings ${ }^{(8-10)}$, use of printed educational material distributed during the sessions(10), home visits $^{(9)}$ and telephone followup $^{(8)}$; which not only improve patients' knowledge about the disease ${ }^{(11)}$, but also affect the self-management of their disease ${ }^{(8)}$.

As for the type of professionals to deliver education, a review of 29 educational intervention studies involving $\mathrm{HF}$ patients ${ }^{(12)}$ revealed that one of the elements that determined their success was the use of nurses with considerable knowledge, especially concerning the teaching and valuation of self-care behaviors.

\section{Aim}

This study aimed to assess the effectiveness of an educational nursing program for the improvement of self-care behaviors in heart failure patients.

\section{Method}

\section{Study design}

Unblinded randomized controlled clinical trial.

\section{Participants}

Patients $\geq 30$ years of age who attended the cardiovascular health program at a hospital institution in Medellín (Colombia) in 2010, with a confirmed HF diagnosis - compatible echocardiogram and clinical symptoms and NYHA functional class from I to III -, without alterations in consciousness levels and who had not reached the terminal phase. Patients were divided between the intervention and control groups, depending on whether or not they received the educational nursing intervention. All patients received the usual care (consultations: medical, nursing, psychology or nutrition) established by the health institution, according to their individual needs, which is why the educational intervention should be considered additional care.

\section{Sample size}

95\% confidence level, $80 \%$ power, minimum proportion of $70 \%$ of patients in the study group versus $30 \%$ in the control group, who improved their self-care behavior score by at least $20 \%$; the minimum sample size was of 24 people in each study group.

Randomization of the intervention: Participants were assigned to the groups with the help of a table with random numbers. A document was elaborated with the randomization keys, in which the numerical codes were arranged in increasing order, preceded by the group corresponding to the previous random designation. Codes were assigned as participants were included in the study, with code 01 for the first person, 02 for the second and so on.

Intervention: The educational activities were aimed at the HF patients and their families. The following five aspects were prioritized for the educational intervention: knowledge on the disease, adherence to pharmacological and non-pharmacological treatment, request for help during the disease, adaptation to life with the disease and the effects of the medication, and self-concept as an element that permits patients' empowerment and motivation for their care and their management of resources to adapt to life with the disease. The duration of the educational nursing program was nine months, during which group encounters were held, as well as telenursing sessions and home visits. To support the intervention activities, the educational booklet "Developing self-care behaviors: a way to cope with heart failure" was designed for use by patients and caregivers. The researchers developed all of these activities. In Figure 1, each of the activities developed with the study groups is detailed. 


\begin{tabular}{|c|c|c|}
\hline \multicolumn{2}{|c|}{ Groups } & \multirow{2}{*}{ Description } \\
\hline Intervention & Control & \\
\hline Enrollment & Enrollment & $\begin{array}{l}\text { During the first month of the research, the informed consent is signed and sociodemographic } \\
\text { and clinical data are collected. }\end{array}$ \\
\hline $\begin{array}{l}\text { Measuring of self-care } \\
\text { behaviors }\end{array}$ & $\begin{array}{l}\text { Measuring of self-care } \\
\text { behaviors }\end{array}$ & $\begin{array}{l}\text { For all patients, baseline self-care behaviors were measured upon enrollment. In the } \\
\text { intervention group, the second measurement happened before the start of the second } \\
\text { educational meeting ( } 8^{\text {th }} \text { month) and, in the control group, before the only meeting ( } 9^{\text {th }} \text { month). }\end{array}$ \\
\hline Home visit & No & $\begin{array}{l}\text { Home visits take place in months } 1 \text { and } 8 \text {, during which patient's basic social conditions } \\
\text { for health care are evaluated. The family and patient receive indications from the nurse to } \\
\text { improve self-care. }\end{array}$ \\
\hline Telenursing & No & $\begin{array}{l}\text { In months } 2,3,4,5,6 \text { and } 7 \text {, self-care was evaluated by phone, using a guide to monitor the } \\
\text { nursing plan recommended during the previous contact. }\end{array}$ \\
\hline $\begin{array}{l}\text { Educational meeting at the } \\
\text { start of the research }\end{array}$ & No & $\begin{array}{l}\text { Took place during the first month. Patients and their families share experiences and } \\
\text { knowledge about: what heart failure is, care for the disease, importance of physical exercise } \\
\text { and stress management techniques. A workshop on healthy cooking is offered afterwards. }\end{array}$ \\
\hline $\begin{array}{l}\text { Educational meeting at the } \\
\text { end of the research }\end{array}$ & $\begin{array}{l}\text { Educational meeting at } \\
\text { the end of the research }\end{array}$ & $\begin{array}{l}\text { Took place in month } 8 \text { in the intervention group, returning to the self-care behavior aspects } \\
\text { observed during telenursing that caused most difficulties; before the educative activity, self- } \\
\text { care behaviors are measured. } \\
\text { In the control group, this activity took place in month } 9 \text {, involving the same activities as during } \\
\text { the first educational meeting with intervention group patients. }\end{array}$ \\
\hline $\begin{array}{l}\text { Distribution of educative } \\
\text { folder during the first } \\
\text { educational meeting }\end{array}$ & $\begin{array}{l}\text { Distribution of educative } \\
\text { folder at the end of the } \\
\text { research }\end{array}$ & $\begin{array}{l}\text { The folder didactically describes: how to plan activities to avoid fatigue, general aspects like } \\
\text { diet, alarm signs of HF decompensation, when to ask for help, adaptation to the therapeutic } \\
\text { regimen, control of weight and ingested and eliminated fluid. In addition, the folder contains a } \\
\text { contract patients should sign to take care of themselves. } \\
\text { This folder also contains tables to control weight, ingested and eliminated fluids and } \\
\text { medication administration. }\end{array}$ \\
\hline
\end{tabular}

Figure 1 - Activities involving the study groups

Figure 2 displays the research flow chart.

Information collection instrument. A four-part instrument was designed, including: a) demographic information: age, gender, marital status, occupation and education level; b) information on social support: family, friends and health institution; c) clinical information: comorbidity, functional class, ejection fraction, hospitalizations and death; and d) Artinian's Heart Failure Self-care Behaviors Scale(13). This scale derives from Dorothea Orem's self-care deficit theory ${ }^{(6)}$, validated for use in Colombia(14) with a Cronbach's alpha of 0.76 (men: 0.73 and women: 0.77 ). This scale comprises 28 items that measure the frequency of selfcare behaviors, distributed in six dimensions (request for help, adaptation to life with the disease, adaptation to therapeutic regimen, awareness-gaining, modifying one's self-concept and self-acceptance, learning to live with heart failure and treatment effects).

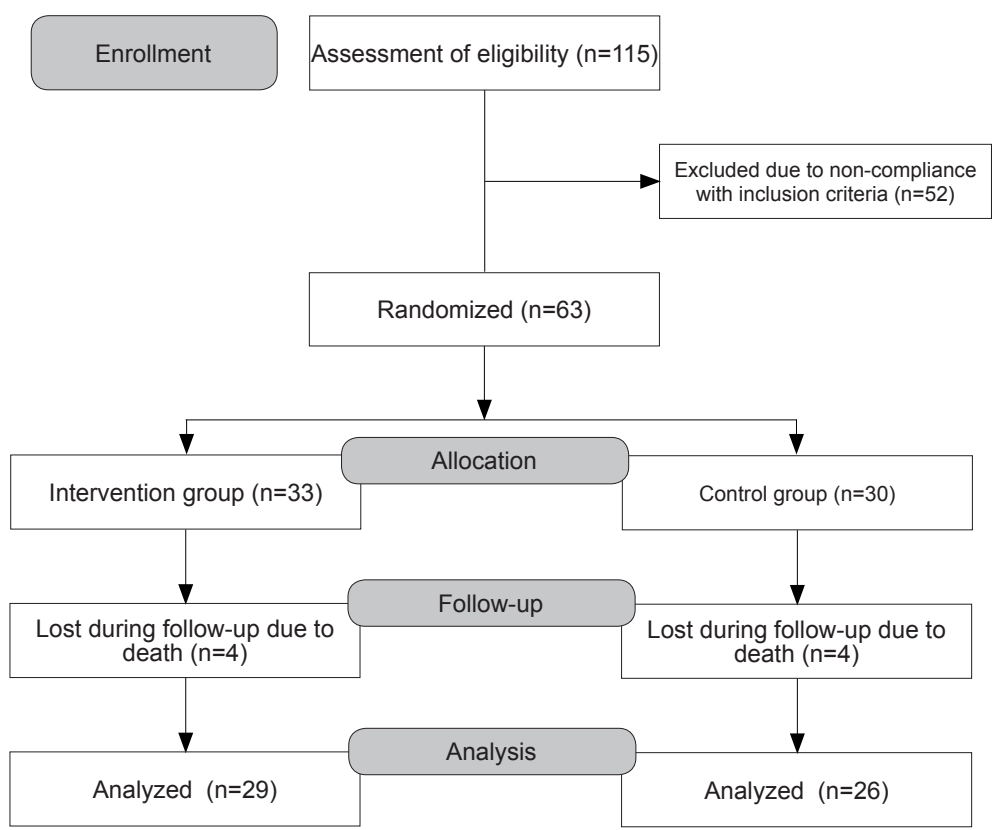

Figure 2 - Research flow chart 
A Likert format was adopted for response alternatives ( 0 =never, $1=$ few times, 2 =most of the time, and $3=$ all the time). Scores are inverse for items 16 and 24 . The total score is the sum of scores for the 28 items, with higher scores corresponding to higher self-care levels.

\section{Data collection}

The patient self-reported data on the self-care scale and sociodemographic and social support variables, while information on clinical variables was obtained directly from the clinical history.

\section{Statistical analysis}

SPSS software, version 19.00 (Chicago, USA) was used to analyze the collected information. The analysis plan was developed according to the proposed objectives. All ratio variables were examined for outliers and non-normal distributions; except for number of hospitalizations, which did not show this type of distribution.

The research variables were compared per study group, using the statistics indicated for independent samples, as follows: a) proportion difference: the $\mathrm{X}^{2}$ was applied for expected counts in the cells of the contingency tables $\geq 5$, if not, Yates' correction for continuity was used; b) difference of means: Student's t-test was used; c) difference of medians: Mann-Whitney's U-test was used. In all cases, statistical significance was assumed for probability values below 0.05. Repeated measures ANOVA was used to assess inter and intra subject variability in self-care scale scores from baseline to the final evaluation. Mauchly's $W$ test was used to assess the sphericity of the variance-covariance matrix. In case of compliance with the sphericity premise, the F-test was used to indicate whether the hypothesis of equality between the study groups could be accepted or rejected, concerning the self-care scale scores at both evaluation moments. The contrast used in this procedure is polynomial to the repeated measure factors, which permitted studying whether the existing relation between the factor (study group) and the dependent variable (self-care score) is linear. To assess the possible confounding and/or interaction effect of certain variables in the relation between the dependent (final self-care scale score at least $20 \%$ better than baseline) and the independent variable (study group), two strategies were used:

a) Stratified analysis. To assess the confounding effect of third variables on the relation under analysis.
Mantel-Haenszel $(\mathrm{M}-\mathrm{H}) \mathrm{X}^{2}$ test was applied, with their respective probability value. It was considered that no confounding effect existed if the Odds Ratios, whether crude or corrected by $\mathrm{M}-\mathrm{H}$, were similar. In addition, it was examined whether the potentially confounding variable moderated the effect, i.e. it was presumed that interaction existed in case of differences in the comparison of the strata's OR.

b) Logistic regression analysis. After the stratification, as described earlier, a stepwise logistic regression model was elaborated. The dependent variable was defined as the percentage of change in the self-care scale scores between baseline and final measure, which was dichotomized with $20 \%$ set at the cut-off, previously established through a consensus among the researchers as a minimum positive change percentage $(\geq 20 \%=1$, $\leq 19 \%=0$ ). The power of the association between the independent and dependent variables was estimated through the constant $e(2,71828)$ and the estimated power of the $\beta$ parameter for the exposure of interest. Statistical significance of the estimated parameter was interpreted according to a probability of less than 0.05 . The final logistic regression model obtained the best goodness-of-fit after simultaneously adjusting for the confounding variables detected in the stratified analysis. The potential interaction effect of the independent variables as possible effect modifying variables was assessed through the OR per stratum, considering that the $\mathrm{CI}_{95 \%}$ would not include 1.0 .

The magnitude of the intervention effect was analyzed by comparing the proportion of patients in both study groups that obtained a self-care scale score at least $20 \%$ better, adopting the intention-to-treat analysis principles, i.e. taking into account all patients from each group in the denominator, even those lost because of death. Then, the absolute increase in the benefit and number needed to treat (NNT) were calculated.

\section{Ethical aspects}

This research received Institutional Review Board approval from the School of Nursing at Universidad de Antioquia. The main ethical aspects respected were: a) signing of informed consent for participation, b) confidentiality of information collected for the research, and c) benefit for the control group: at the end of the study, control group patients received a four-hour educational session, during which the main themes addressed during the activities developed with the intervention group were presented. In addition, these patients received the educational booklet. 
This research is registered under code COL321 in the Latin American Ongoing Clinical Trial Register (LATINREC) of the Iberoamerican Cochrane Network.

\section{Results}

In this study, 33 people participated in the intervention group and 30 in the control group. Table 1 shows that both study groups have comparable characteristics, which significant differences for the variables main activity developed during the day (25.0\% in the intervention group versus $56.7 \%$ in the control group develop no activities) and education level $(27.3 \%$ in the intervention group versus $43.3 \%$ in the control group have no degree) only. In general terms, one may say that most of the participants were older adults, married, in socioeconomic group 2, with a primary or higher education degree and who received support mainly from family and health institutions. Concerning the clinical variables, without group distinctions, most patients were classified in NYHA functional class 2, with an ejection fraction below $50 \%$ and arterial hypertension, diabetes mellitus and congestive heard disease as the main comorbidities. During the study period, nine out of ten patients in the intervention group and eight out of ten patients in the control group were hospitalized, -with one as the median hospitalization number in both group -, and one out of ten patients in each group died due to causes linked to their HF.

Table 1 - General and clinical characteristics of participants in the intervention and control groups. Medellin, Colombia 2010

\begin{tabular}{|c|c|c|c|c|}
\hline \multirow{2}{*}{ Variables } & \multicolumn{2}{|c|}{ Group } & \multirow{2}{*}{ Statistics } & \multirow{2}{*}{ Bilateral $p$-value } \\
\hline & $\begin{array}{c}\text { Intervention } \\
(n=33)\end{array}$ & $\begin{array}{c}\text { Control } \\
(n=30)\end{array}$ & & \\
\hline \multicolumn{5}{|l|}{ Demographic variables } \\
\hline Age; mean \pm standard deviation & $65.4 \pm 12.3$ & $70.5 \pm 10.3$ & $1.77^{\star}$ & 0.080 \\
\hline Male gender; n (\%) & $14(43.8)$ & $17(56.7)$ & $1.03^{\dagger}$ & 0.446 \\
\hline Stratum; mean \pm standard deviation & $2.6 \pm 0.8$ & $2.3 \pm 0.9$ & $1.56^{*}$ & 0.124 \\
\hline \multicolumn{5}{|l|}{ Marital status; $n(\%)$} \\
\hline Single & $5(15.6)$ & $1(3.3)$ & $6.20^{\ddagger}$ & 0.185 \\
\hline Married & $17(53.1)$ & $20(66.7)$ & & \\
\hline Separated & $1(3.1)$ & $2(6.7)$ & & \\
\hline Widowed & $7(21.9)$ & $7(23.3)$ & & \\
\hline Fixed partner & $2(6.3)$ & $0(0.0)$ & & \\
\hline Primary education degree or higher; $\mathrm{n}(\%)$ & $23(71.8)$ & $17(56.6)$ & $1.56^{+}$ & 0.211 \\
\hline \multicolumn{5}{|l|}{ Main activity during the day; $\mathrm{n}(\%)$} \\
\hline None & $8(25.0)$ & $17(56.7)$ & \multirow{4}{*}{$5.03^{\ddagger}$} & \multirow{4}{*}{0.02} \\
\hline Housework & $19(59.4)$ & $11(36.7)$ & & \\
\hline Job & $2(6.3)$ & $1(3.3)$ & & \\
\hline Leisure & $3(9.4)$ & $1(3.3)$ & & \\
\hline \multicolumn{5}{|l|}{ Receive support from $\S$} \\
\hline Family; n (\%) & $25(78.1)$ & $26(86.7)$ & $0.77^{\ddagger}$ & 0.379 \\
\hline Friends; n (\%) & $5(15.6)$ & $4(13.3)$ & $0.06^{\ddagger}$ & 0.798 \\
\hline Health institution; $\mathrm{n}(\%)$ & $12(37.5)$ & $11(36.7)$ & $0.005^{\dagger}$ & 0.946 \\
\hline None; n (\%) & $4(12.5)$ & $2(6.7)$ & $0.12^{\ddagger}$ & 0.729 \\
\hline \multicolumn{5}{|l|}{ Clinical variables } \\
\hline NYHA class; mean \pm standard deviation & $2.2 \pm 0.7$ & $2.2 \pm 0.6$ & $0.09^{*}$ & 0.928 \\
\hline Ejection fraction; mean \pm standard deviation & $41.7 \pm 16.2$ & $46.0 \pm 17.4$ & $-0.66^{*}$ & 0.507 \\
\hline \multicolumn{5}{|l|}{ Comorbidity } \\
\hline Arterial hypertension; $\mathrm{n}(\%)$ & $27(84.4)$ & $24(80.0)$ & $0.20^{+}$ & 0.746 \\
\hline Chronic renal failure; $\mathrm{n}(\%)$ & $6(18.8)$ & $4(13.3)$ & $0.05^{\ddagger}$ & 0.562 \\
\hline Diabetes Mellitus; $\mathrm{n}(\%)$ & $9(28.1)$ & $12(40.0)$ & $0.97^{\dagger}$ & $\begin{array}{l}0.323 \\
\text { (continue... }\end{array}$ \\
\hline
\end{tabular}


Table 1 - (continuation)

\begin{tabular}{|c|c|c|c|c|}
\hline \multirow{2}{*}{ Variables } & \multicolumn{2}{|c|}{ Group } & \multirow{2}{*}{ Statistics } & \multirow{2}{*}{ Bilateral p-value } \\
\hline & $\begin{array}{l}\text { Intervention } \\
\quad(n=33)\end{array}$ & $\begin{array}{l}\text { Control } \\
(n=30)\end{array}$ & & \\
\hline Congestive heart disease; n (\%) & $12(37.5)$ & $7(24.1)$ & $1.26^{\dagger}$ & 0.260 \\
\hline Dislypidemias; n (\%) & $4(12.5)$ & $6(20.0)$ & $0.63^{\ddagger}$ & 0.426 \\
\hline Chronic Obstructive Pulmonary Disease; n (\%) & $2(6.2)$ & $3(10.0)$ & $0.29^{\ddagger}$ & 0.587 \\
\hline Cerebrovascular disease; $\mathrm{n}(\%)$ & $1(3.1)$ & $1(3.3)$ & $0.00^{\ddagger}$ & 0.962 \\
\hline Depression; n (\%) & $1(3.1)$ & $1(3.3)$ & $0.00^{\ddagger}$ & 0.962 \\
\hline \multicolumn{5}{|l|}{ Hospitalizations } \\
\hline Were hospitalized; n (\%) & $30(93.7)$ & $24(80.0)$ & $2.60^{\ddagger}$ & 0.106 \\
\hline Number of hospitalizations; median quartile 1, quartile 2) & $1.0(1.0,2.3)$ & $1.0(1.0,2.0)$ & $455.50^{\|}$ & 0.895 \\
\hline Death by HF; n (\%) & $4(12.1)$ & $4(13.3)$ & $0.00^{\ddagger}$ & 1.000 \\
\hline
\end{tabular}

*Student's t for independent samples

'Pearson's $X^{2}$

${ }^{\ddagger} X^{2}$ with Yates' correction

${ }^{\S}$ Are not exclusive

"Mann-Whitney's U

\section{Analysis of repeated measures}

In this study, 29 patients from the intervention group and 26 patients from the control group completed both self-care scale evaluations. In the ANOVA model with repeated measures, Mauchly's W corresponded to 1.00. Therefore, sphericity was assumed and the F-test was used $(F=42.78, p<0.001)$, which indicated a linear relation between the score and the study group. Table 2 also reveals that, although both groups got better scores over time, the difference between both assessment times corresponds to 12.2 points in the intervention group, against only 5.1 points in the control group.

Table 2 - Mean self-care scale scores in 29 intervention group and 26 control group patients according to the evaluation moment. Medellin, Colombia, 2010

\begin{tabular}{ccccc}
\hline \multirow{2}{*}{ Group } & Evaluation & $\begin{array}{c}\text { Mean } \pm \text { standard } \\
\text { deviation }\end{array}$ & \multicolumn{2}{c}{$\begin{array}{c}\text { 95\% confidence } \\
\text { interval of means }\end{array}$} \\
\cline { 4 - 5 } & Initial & $40.0 \pm 6.2$ & $\begin{array}{c}\text { Lower } \\
\text { limit }\end{array}$ & $\begin{array}{c}\text { Upper } \\
\text { limit }\end{array}$ \\
\hline Intervention & Final & $52.2 \pm 10.1$ & 47.7 & 42.2 \\
\multirow{2}{*}{ Control } & Initial & $43.4 \pm 5.7$ & 41.0 & 55.7 \\
& Final & $48.5 \pm 9.0$ & 44.9 & 52.4 \\
\hline
\end{tabular}

\section{Control of confounding variables}

As observed in Table 3, there was practically no confounding effect in the variables that measured support from family and friends and no support; this was the case for the remaining variables: the OR was underestimated for gender and institutional support, but overestimated for the development of some activity during the day. Concerning interaction with variables in the stratification, this was strong for the variables: gender (higher in men), support from friends (higher in participants who received support), education level (higher among participants with a degree) and development of some daytime activity (higher in participants with activities). 
Table 3 - Stratification of possible confounding variables for the relation between at least $20 \%$ of improvement in final score and study group. Medellín, Colombia, 2010

\begin{tabular}{|c|c|c|c|c|c|}
\hline \multirow{2}{*}{ Variables } & \multicolumn{2}{|c|}{ Group } & \multirow{2}{*}{ Statistics } & \multirow{2}{*}{$\begin{array}{c}\text { Bilateral } \\
p \text {-value }\end{array}$} & \multirow{2}{*}{$\mathrm{OR}\left(\mathrm{Cl}_{95 \%} \mathrm{OR}\right)$} \\
\hline & $\begin{array}{l}\text { Intervention } \\
\quad(n=29)\end{array}$ & $\begin{array}{l}\text { Control } \\
(n=26)\end{array}$ & & & \\
\hline \multicolumn{6}{|l|}{ Gender } \\
\hline Female & $56.3 \%$ & $27.3 \%$ & $1.19^{\dagger}$ & 0.27 & $3.4(0.6-17.9)$ \\
\hline Male & $84.6 \%$ & $33.3 \%$ & $5.53^{\dagger}$ & 0.01 & $11.0(1.7-69.9)$ \\
\hline Adjusted by $\mathrm{M}-\mathrm{H}$ & - & - & $7.15^{\ddagger}$ & $<0.01$ & $5.8(1.7-19.5)$ \\
\hline \multicolumn{6}{|l|}{ Age group } \\
\hline$<60$ years & 54.5 & 25.0 & $0.18^{\dagger}$ & 0.66 & $3.6(0.3-46.3)$ \\
\hline $60-69$ years & 75.0 & 20.0 & $1.85^{\dagger}$ & 0.17 & $12.1(0.7-180.9)$ \\
\hline $70+$ years & 69.0 & 30.8 & $3.41^{\dagger}$ & 0.06 & $7.3(1.1-46.2)$ \\
\hline Adjusted by $\mathrm{M}-\mathrm{H}$ & - & - & $7.32^{\ddagger}$ & $<0.01$ & $6.7(1.9-24.9)$ \\
\hline \multicolumn{6}{|l|}{ Family support } \\
\hline Yes & $68.2 \%$ & $36.4 \%$ & $4.46^{*}$ & 0.03 & $3.7(1.1-13.0)$ \\
\hline No & $71.4 \%$ & $0.0 \%$ & $2.75^{\dagger}$ & 0.09 & $3.0(0.9-9.3)$ \\
\hline Adjusted by $\mathrm{M}-\mathrm{H}$ & - & - & $6.62^{\ddagger}$ & 0.01 & $5.1(1.6-16.6)$ \\
\hline \multicolumn{6}{|l|}{ Support from friends } \\
\hline Yes & $75.0 \%$ & $25.0 \%$ & $0.50^{\dagger}$ & 0.48 & $9.0(0.3-220.9)$ \\
\hline No & $68.0 \%$ & $31.8 \%$ & $6.13^{*}$ & 0.01 & $4.5(1.3-15.6)$ \\
\hline Adjusted by $\mathrm{M}-\mathrm{H}$ & - & - & $6.29^{\ddagger}$ & 0.01 & $4.9(1.5-15.6)$ \\
\hline \multicolumn{6}{|l|}{ Institutional support } \\
\hline Yes & $58.3 \%$ & $22.2 \%$ & $1.4^{\dagger}$ & 0.22 & $4.9(0.7-34.3)$ \\
\hline No & $76.5 \%$ & $35.3 \%$ & $4.29^{\dagger}$ & 0.03 & $5.9(1.3-26.6)$ \\
\hline Adjusted by $\mathrm{M}-\mathrm{H}$ & - & - & $6.77^{\ddagger}$ & $<0.01$ & $5.5(1.7-14.7)$ \\
\hline \multicolumn{6}{|l|}{ No support } \\
\hline Yes & $75.0 \%$ & $0.0 \%$ & $4.58^{\dagger}$ & 0.03 & $3.0(0.6-14.8)$ \\
\hline No & $68.0 \%$ & $33.3 \%$ & $5.88^{*}$ & 0.01 & $4.2(1.2-14.0)$ \\
\hline Adjusted by $\mathrm{M}-\mathrm{H}$ & - & - & $6.39^{\ddagger}$ & 0.01 & $5.0(1.6-15.8)$ \\
\hline \multicolumn{6}{|l|}{ Education level } \\
\hline Primary and higher & $65.0 \%$ & $31.3 \%$ & $4.05^{*}$ & 0.04 & $4.1(1.1-16.6)$ \\
\hline None & $77.8 \%$ & $30.0 \%$ & $2.63^{\dagger}$ & 0.10 & $8.2(1.0-64.9)$ \\
\hline Adjusted by $\mathrm{M}-\mathrm{H}$ & - & - & $6.42^{\ddagger}$ & 0.01 & $5.1(1.6-16.2)$ \\
\hline \multicolumn{6}{|c|}{ Develops some daytime activity } \\
\hline Yes & $72.7 \%$ & $27.3 \%$ & $4.48^{\dagger}$ & 0.03 & $7.1(1.4-36.1)$ \\
\hline No & $57.1 \%$ & $33.3 \%$ & $0.35^{\dagger}$ & 0.55 & $2.6(0.4-16.8)$ \\
\hline Adjusted by $\mathrm{M}-\mathrm{H}$ & - & - & $5.15^{\ddagger}$ & 0.02 & $4.6(1.5-15.4)$ \\
\hline Crude data & - & - & 8.00 & $<0.01$ & $5.0(1.6-15.7)$ \\
\hline
\end{tabular}

*Pearson's $\mathrm{X}^{2}$

${ }^{+} X^{2}$ with Yates' correction

${ }^{\ddagger} \mathrm{X}^{2}$ by Mantel and Haensze

\section{Logistic regression}

The logistic regression model with the best goodness-of-fit $\left(X^{2}=15.11, p=0.004\right)$, after simultaneous adjustment for confounding variables detected among those listed in Table 4, found a statistically significant relation $(p<0.001)$ with the variables study group and level. In the first, the probability of a better self-care level is 5.9 times higher in the intervention than in the control group $\left(\mathrm{CI}_{95 \%} \mathrm{OR}=1.7-20.8\right)$; and, concerning education level, for every person without a degree who improves the self-care score by at least $20 \%$, there are $1.6\left(\mathrm{CI}_{95 \%} \mathrm{OR}=1.2-2.0\right)$ people with a primary education and $6.1\left(\mathrm{CI}_{95 \%} \mathrm{OR}=5.6-6.9\right)$ people with a secondary degree who also improved.

\section{Effectiveness of the educational program to improve self-care}

The intention-to-treat analysis showed that $66.0 \%$ $\left(\mathrm{CI}_{95 \%}: 42.1 \%-76.5 \%\right)$ of the intervention group, versus $26.6 \%\left(\mathrm{CI}_{95 \%}: 12.9 \%-46.1 \%\right)$ of the control group, improved their self-care scale score by at least $20 \%$, with a statistically significant difference $\left(X^{2}=7.33, p=0.006\right)$, for an OR of $4.2\left(\mathrm{CI}_{95 \%}: 1.4-12.3\right)$. The absolute difference between the groups for an improvement of at least $20 \%$ in the scale score under analysis corresponded to $39.4 \%\left(\mathrm{CI}_{95 \%}: 16.8 \%-62.0 \%\right)$, while the NNT equaled $2.5\left(\mathrm{CI}_{95 \%}: 1.6-5.9\right)$, which means that 2.5 people have to be treated with the educational intervention for one to improve his/her self-care score by at least $20 \%$. 


\section{Discussion}

In this study, in which the effectiveness of a nursing educational program was evaluated to improve the selfcare of HF patients, although both groups improved their mean score on the scale used for the first and second assessment, people who received the intervention revealed a substantial change in comparison with the control group. This is in line with a study in which the quality of life of HF patients was assessed before and after an educational intervention(5), and with another in which the knowledge, behaviors, satisfaction and quality of life of HF patients who attended an educational program with nursing participation was compared with a control group ${ }^{(15)}$. The better self-care score in the control group, although not to the same extent as in the intervention group, can be attributed to the fact that all patients involved in this research continued to receive the regular care the health institution offered, which included education by health professionals. Therefore, the improvement in self-care behaviors could also be due to the learning achieved in that way ${ }^{(16)}$ during the followup time in this study. The absolute difference between the groups for the improvement of at least $20 \%$ in the self-care scale score corresponded to $39 \%$, which can be considered high and corresponds to the effect that could be attributed to the educational intervention.

The NNT found was 2.5, which indicates an additional goodness of the intervention, as, after receiving the intervention for at least seven months, one in every 2.5 patients would improve his/her self-care scale score by at least $20 \%$. This is very promising, even without calculating the cost-benefit of the economic resources saved in the treatment of HF complications, without mentioning the increased quality of life of patients with this condition.

Considering that educational programs not only aim to improve knowledge, but also the behaviors that influence the disease ${ }^{(17-18)}$, in our study, we developed $\mathrm{HF}$ activities that had already been reported on as effective in other studies that involved HF patients(11). Other researchers have frequently used the following: educational meetings between patients and their caregivers $^{(8-10)}$, home visits ${ }^{(9)}$ - with the additional advantage of permitting the adaptation of education to the conditions the HF patients live in -(19) and telenursing ${ }^{(8)}$. In literature, print material is evaluated as a valuable support strategy for all activities in the educational programs, helping patients to assimilate the large information volume that is being offered(9-10).
In view of the results of educational interventions that included print material for patients with low reading levels, associated with improvements in self-care behaviors and the acknowledgement of signs and symptoms of worse disease conditions(20), in our study, an educational booklet was designed, for use by all stakeholders in the intervention, but mainly by patients who participated in the study and whose educational level was low. Patients and their caregivers opined that the folder was understandable, clear and pleasant to read.

In our study, we also included the family in the educational activities, as well-known literature exists that emphasizes that much of these programs' success is related with the family members' support to patients in practicing protective conducts against $\mathrm{HF}^{(21-22)}$. In our data, the proportion of patients who received family support was the same in both groups, so that this variable did not produce any confusion. We did not find any difference either in the improved self-care scale score between men and women in both groups, in line with a cross-sectional study(23), but different from a research in which women showed a worse functional state, which was associated with worse selfcare practices $^{(24)}$. This can result from the fact that, in our study, gender and functional class variables were controlled as confounding variables: the first in the stratified and multivariate analyses, and the second by using the restrictive selection criterion that participants should be classified in NYHA functional class III at most.

These study findings showed no age differences in the self-care scale score increase, in line with another study ${ }^{(23)}$, but differ from a research in which age was directly associated with a greater probability of some conducts, including turning to the physician in case of health problems ${ }^{(13)}$.

The logistic regression analysis showed a positive relation between educational level and the improved self-care score, in line with literature reports(13), especially concerning conducts related to adherence to the prescribed pharmacological treatment. Although some authors ${ }^{(7,25)}$ showed in their studies that nursing educational interventions offer undeniable benefits to reduce the probability of readmission and death due to $\mathrm{HF}$, in the present study, these differences were not found between the two groups, possibly due to the ninemonth duration of follow-up, which could be considered short to assess these results. 


\section{Conclusion}

These research results suggest that a nursing educational intervention like the one presented in this paper exerts beneficial effects on the improvement of self-care behaviors in HF patients. One limitation is that it cannot be guaranteed which of the nursing educational interventions more strongly influenced the change in self-care scale scores, which could be a theme for further research.

\section{References}

1. Lindenfeld J, Albert NM, Boehmer JP, Collins SP, Ezekowitz JA, Givertz MM, et al. Executive Summary: HFSA 2010 Comprehensive Heart Failure Practice Guideline. J Card Fail. 2010;16(6):475-53.

2. Albert N. Evidence-based nursing care for patients with heart failure. AACN Adv Crit Care. 2006;17(2):170-83.

3. Achury D. Adherencia al tratamiento en el paciente con falla cardiaca. In: Rincón F, Díaz E, editors. Enfermería cardiovascular. Bogotá: Sociedad Colombiana de Cardiología; 2008. p. 342-68.

4. Rodríguez-Artalejo F, Banegas J, Guallar-Castillón P. Epidemiología de la insuficiencia cardíaca. Rev Esp Cardiol. 2004;57(2):163-70.

5. Scott $L$, Setter-Kliner $K$, Britton A. The effects of nursing interventions to enhance mental health and quality of life among individuals with heart failure. Appl Nurs Res. 2004;17(4):248-56.

6. Renpenning K, Taylor S. Self-care t theory of nursing: selected papers of Dorothea Orem. New York: Springer Publisher; 2003.

7. Evangelista L, Doering L, Dracup K, Hamilton M. Compliance behaviors of elderly patients with advanced heart failure. J Cardiovasc Nurs. 2003;18(3):197-206.

8. Krumholz H, Amatruda J, Smith G. Randomized trial of an education and support intervention to prevent readmission of patients with heart failure. J Am Coll Cardiol. 2002;39(1):83-9.

9. Jaarsma T, Huijer Abu-Saad H. Effects of education and support on self-care and resource utilization in patients with heart failure. Eur Heart J. 1999;20(9):673-82.

10. Harrison M, Browne G, Roberts J. Quality of life of individuals with heart failure: a randomized trial of the effectiveness of two models of hospital-to-home transition. Med Care. 2002;40(4):271-82.
11. Hope C, Wu J, Tu W. Association of medication adherence, knowledge, and skills with emergency department visits by adults 50 years or older with congestive heart failure. Am J Health Syst Pharm. 2004;61(19):2043-9.

12. McAlister F, S. S, Ferrua S. Multidisciplinary strategies for the management of heart failure patients at high risk for admission. A systematic review of randomized trials.

J Am Coll Cardiol. 2004;44(4):810-9.

13. Artinian N, Morris M, Sloan M, Lange P. Self-care behaviors among patients with heart failure. Issues Cardiovasc Nurs Heart Lung. 2002;31(3):161-72.

14. Arredondo E, Rodríguez-Gázquez M. Validación de una escala de evaluación de comportamientos de autocuidado de adultos con falla cardiaca. Medellín: Facultad de Enfermería de la Universidad de Antioquia; 2009.

15. Baker DW, Asch SM, Keesey JW, Brown JA, Chan KS, Joyce $G$, et al. Differences in education, knowledge, selfmanagement activities, and health outcomes for patients with heart failure cared for under the chronic disease model: the improving chronic illness care evaluation. J Card Fail. 2005;11(6):405-13.

16. Carlson B, Riegel B, Moser DK. Self-care abilities of patients with heart failure. Heart Lung. 2001;30(5):351-9.

17. Rankin S, Stallings K. Patient education, principles and practice. 4th ed. Philadelphia: Lippincott Williams and Wilkins; 2001.

18. Pelegrino VM, Dantas RAS, Clark AM. Health-related quality of life determinants in outpatients with heart failure. Rev. Latino-Am. Enfermagem. 2011;19(3):451-7. 19. Dickson V, McMahon J. Optimal patient education and counseling. In: Moser D, Riegel B, editors. Cardiac Nursing: A Companion to Braunwald's Heart Disease. St Louis: Saunders Elsevier; 2008. p. 1263-82.

20. DeWalt D, Pignone M, Malone R. Development and pilot testing of a disease management program for low literacy patients with heart failure. Patient Educ Couns. 2004;55(1):78-86.

21. Phillips C, Wright S, Kern D, Singa R. Comprehensive discharge planning with postdischarge support for older patients with congestive heart failure: a meta-analysis. JAMA. 2004;219(11):1358-67.

22. Doughty $R$, Wright $S$, Pearl A. Randomized, controlled trial of integrated heart failure management: the Auckland Heart Failure Management Study. Eur Heart J. 2002;23(2):139-49. 
23. Heo S, Moser DK, Lennie TA, Riegel B, Chung $M L$. Gender differences in and factors related to self-care behaviors: a cross-sectional, correlational study of patients with heart failure. Int J Nurs Stud. 2008;45(12): 1807-15.

24. Friedman MM. Gender differences in the health related quality of life of older adults with heart failure. Heart Lung. 2003;32(5):320-7.

25. Rabelo ER, Aliti GB, Domingues FB, Ruschel KB, Brun AO. What to teach to patients with heart failure and why: the role of nurses in heart failure clinics. Rev. Latino-Am. Enfermagem. 2007;15(1):165-70. 